\title{
Scientific Training and its Relation with the Professional Training of Psychologists
}

\author{
Valquiria Maria Gonçalves ${ }^{1}$ \\ Nádia Kienen \\ Verônica Bender Haydu \\ Programa de Mestrado em Análise do Comportamento e Departamento de Psicologia Geral \\ e Análise do Comportamento da Universidade Estadual de Londrina, Londrina, PR, Brazil
}

\begin{abstract}
A literature review was conducted to identify how scientific training contributes to the professional training of psychologists. In scientific databases, fourteen papers relating to scientific training of psychologists as part of their professional training during their degree courses were selected. Based on the identification of characteristics such as their nature, aims, methods and findings, categories were formulated in order to analyze the results of the studies, namely: (a) conception of research, scientific training and participation in research activity; (b) reflection on the importance of scientific training for the professional training of psychologists; (c) characterization of professional behaviors related to the scientific training of psychologists; (d) characteristics of teaching goals present in course plans and teaching plans for scientific training as part of Psychology degree courses; (e) teaching programs to develop professional behaviors as part of the scientific training of psychologists. A noteworthy finding is students' unawareness about the possibility of participating in research activities and the relevance of the characterization of scientific and professional behaviors.
\end{abstract}

Keywords: Scientific training, psychologists' formation, professional training, Teaching Programming, literature review.

\section{Formação Científica e sua Relação com a Capacitação Profissional do Psicólogo}

\section{Resumo}

Uma revisão bibliográfica foi realizada para identificar as contribuições da formação científica para a capacitação profissional do psicólogo. Em bases de dados científicas, foram selecionados 14 trabalhos sobre formação científica do psicólogo e sua capacitação profissional. A partir da identificação de características como natureza do trabalho, objetivos, método e contribuições apresentadas, foram formuladas as categorias para análise dos resultados, sendo essas: (a) concepção sobre pesquisa, formação científica e participação em atividade de pesquisa; (b) reflexão sobre a importância da formação científica para a capacitação profissional do psicólogo; (c) caracterização de comportamentos profissionais relativos à formação científica do psicólogo; (d) características dos objetivos de ensino presentes nos planos de curso e de ensino de disciplinas relacionadas à capacitação científica na

Mailing adress: Universidade Estadual de Londrina, Centro de Ciências Biológicas, Departamento de Psicologia Geral e Análise do Comportamento, Rodovia Celso Garcia Cid, PR 445, Km 380, Campus Universitário, Caixa Postal 10.011, Londrina, PR, Brazil 86057-970. E-mail: valk.mg@gmail.com, nadiakienen@gmail.com and veronicahaydu@gmail.com

Financial support: Coordenação de Aperfeiçoamento de Pessoal de Nível Superior (CAPES) and Fundação Araucária. 
graduação em Psicologia; (e) programas de ensino de comportamentos profissionais que compõem a formação científica do psicólogo. Destaca-se o desconhecimento dos alunos sobre a possibilidade de participação em atividades de pesquisa e a relevância da caracterização de comportamentos científicos/ profissionais.

Palavras-chave: Formação científica, formação do psicólogo, formação profissional, Programação de Ensino, revisão da bibliografia.

\section{Formación Científica y su Relación con la Capacitación Profesional del Psicólogo}

\section{Resumen}

Una revisión bibliográfica fue realizada para identificar las contribuciones de la formación científica en la capacitación profesional del psicólogo. En bases de dados científicas, fueron seleccionados 14 trabajos sobre la formación científica del psicólogo y su capacitación profesional. A partir de la identificación de categorías como naturaleza del trabajo, objetivos, método y las contribuciones realizadas, fueron formuladas las categorías para el análisis de los resultados, siendo ellas: (a) concepción al respecto de la investigación, formación científica y participación en actividades de investigación; (b) reflexión sobre la importancia de la formación científica para la formación profesional del psicólogo; (c) caracterización de la conducta profesional con respecto a la formación científica del psicólogo; (d) características de los objetivos de la enseñanza presentes en el programa del curso y de la enseñanza de materias relacionadas con la formación científica en Psicología; (e) programas de enseñanza de conductas profesionales que componen la formación científica del psicólogo. Destacarse la ignorancia de los estudiantes acerca de la posibilidad de participar en actividades de investigación y la relevancia de la caracterización de las conductas científicas/profesionales.

Palabras clave: Formación científica, formación del psicólogo, formación profesional, programación de la educación, revisión de la literatura.

One of the areas for which the Psychology professional should be trained during degree course is the scientific area. This training requires the development of behaviors such as observing, formulating questions, seeking literature, evaluating the best method of intervention, checking results, among other behaviors. The development of these skills is essential so the professionals in this area to be able to produce knowledge and transform it into technology. This is considered a key factor not only to the training of any professional, but also to the development of a nation (Viecili, 2008).

Since the profession of psychologists was regulated in Brazil in 1962, and also after years of discussion about the role and importance of scientific training as part of Psychology degree courses, the space for this training has been guaranteed in legal terms by the National Curricular Guidelines for Psychology Degree
Courses, through Resolution $\mathrm{n}^{\circ}$ 5, dated March $15^{\text {th }} 2011$ (Ministério da Educação, Conselho Nacional de Educação/Câmara da Educação Superior, 2011). Besides presenting as "central goal the psychologist training oriented towards professional activities, research and Psychology teaching" (Art. 3), these guidelines highlight that, for this goal to be achieved, certain principles and commitments should be observed such as "Creation and development of scientific knowledge in Psychology", among others, many of which related to scientific training. However, psychologists, researchers and psychology professors have discussed at scientific meetings and in the professional category the gap between theory, research and intervention in education and psychologist's practice, which result in low quality problems of the scientific production and use of ineffective practices to meet the various social demands (Cruces, 2008). 
Evidences of this gap were mentioned by Bariani (1995) and Silva (2007), indicating that when some professionals, after completing their undergraduate courses, take their studies further, that is, enroll in postgraduate courses, they have difficulties. Thus, it is observed, in certain cases, a lack of knowledge on aspects of scientific methodology relevant for developing their projects and producing knowledge. This can result in research with shortcomings that compromise the quality of what has been produced (Bariani, 1995; Silva, 2007), indicating that teaching was not able to ensure the development of scientific behavior.

Even at postgraduate level scientific training's goal might not have been fulfilled as it was expected. An example of this was found by Silva (2007) who examined the general class of behaviors in relation to "delimiting the research problem", based on the analysis of dissertations written by students taking a postgraduate Psychology course. The author concluded that it was not clear to the majority of the authors of the dissertations how they should set forth the research problem. Silva (2007) concluded that behaviors related to "delimiting the research problem" are possibly still not being taught to postgraduate students.

A review of Psychology literature regarding scientific training and professional training may provide points for the discussion about the training received by psychologists. In addition, such a review can be used in order to identify how shortcomings in the teaching of behaviors related to research at graduation level present themselves and how they are characterized, as well as to verify whether alternatives to these shortcomings are presented. Based on the above considerations, the purpose of this study was to assess the contributions of scientific training to the professional training of psychologists during their degree course through review of relevant literature to the topic. The review was therefore performed on Psychology studies providing results on scientific training and its relationship with the training of future psychologists during their degree courses.

\section{Method}

This is a theoretical study conducted based on data from academic production on the subject of the scientific training of psychologists. The material was selected by means of a review of the literature held on on-line databases via the CAPES (Coordenação de Aperfeiçoamento de Nivel Superior) portal available at http://periodicos.capes.gov.br. Two databases in Portuguese with contents related to Psychology were accessed (IndexPsi and SciELO [Scientific Electronic Library Online]). A search was also done on two on-line dissertation and thesis repositories (Biblioteca Digital de Teses e Dissertações [BDTD] and the Psychology Postgraduate Program archives of the Federal University of Santa Catarina's Repositório de Conteúdo Digital).

Based on the theme chosen, the following keywords were defined to search the databases in Portuguese: formação científica, formação em pesquisa, psicologia, psicólogo, formação do psicólogo, pesquisa psicológica, metodologia científica, metodologia em pesquisa, capacitação científica, capacitação profissional (In English: scientific training, research training, Psychology, psychologist, psychologist training, psychological research, scientific methodology, research methodology, professional training). Studies were surveyed containing such terms anywhere in the text. These terms were searched for individually and also using Boolean operators in the "advanced search" mode of the databases, in order to refine the search results in accordance with the objective of the study.

The titles and the abstracts of the academic production returned by the search were analyzed in order to select those dealing with the theme of scientific training and its relation with the training of psychologists at degree course. All publications that did not specify this theme were excluded.

The main keywords relating to the theme were searched on the BDTD library (available at http://bdtd.ibict.br) in the "Abstract" field of the advanced search. The keywords (in Portuguese) were: formação do psicólogo, formação 
científica, formação em pesquisa, capacitação cientifica and metodologia cientifica (In English: psychologist training, scientific training, research training and scientific methodology). In the same way as above, the titles and abstracts of the publications found were analyzed in order to select those related to the theme of our study. This resulted in one document being selected.

A search was also made on the Psychology Postgraduate Program archives of the Federal University of Santa Catarina's Repositório de Conteúdo Digital. The choice of this database was made because one of the Program's research lines covers psychologist training, including scientific training. The supervisors of this research are Prof. Sílvio Paulo Botomé and Prof. Olga Mitsue Kubo. It should be noted that the document selected in the BDTD database had also been produced by this Program.

As a starting point the documents were read either completely or partially to identify the aspects and information presented in each one of them, namely: theme, objective, type of research (theoretical, empirical, etc.), nature of the publication (paper, thesis, dissertation), method used, as well as the discussions and conclusions presented.
Following this categories were created in order to analyze the documents included in the sample. The categories were formulated considering the objectives of each document and the considerations contained in them. These were grouped together according to similarity. The analysis categories formulated were: (a) conception of research, scientific training and participation in research activity; (b) reflection on the importance of scientific training for the professional training of psychologists; (c) characterization of professional behaviors related to the scientific training of psychologists; (d) characteristics of teaching goals present in course plans and teaching plans for scientific training as part of Psychology degree courses; (e) teaching programs to develop professional behaviors as part of the scientific training of psychologists.

\section{Results and Discussion}

The number of articles originally found, selected and retrieved in the search with each researched descriptor is distributed in Table 1. It can be observed that only the keywords "Formação em pesquisa" and "Formação do psicólo-

Table 1

Descriptors Researched in Databases and Number of Articles Initially Found, Selected and Retrieved for Analysis

\begin{tabular}{cccc}
\hline Descriptors researched in databases & $\begin{array}{c}\text { Number of articles } \\
\text { found }\end{array}$ & $\begin{array}{c}\text { Number of articles } \\
\text { selected }\end{array}$ & $\begin{array}{c}\text { Number of articles } \\
\text { retrieved }\end{array}$ \\
\hline Formação científica & 124 & 6 & 0 \\
Formação em pesquisa & 137 & 8 & 2 \\
Formação do psicólogo & 39 & 4 & 2 \\
Pesquisa psicológica & 25 & 0 & 0 \\
Capacitação científica & 41 & 0 & 0 \\
Capacitação Profissional & 38 & 0 & 0 \\
Formação científica AND Psicólogo & 19 & 4 & 1 \\
Formação em pesquisa AND Psicólogo & 14 & 2 & 1 \\
Metodologia científica AND Psicologia & 37 & 3 & 1 \\
Metodologia de pesquisa AND Psicologia & 32 & 2 & 0 \\
Capacitação cientíica AND Psicólogo & 1 & 0 & 0 \\
Capacitação profissional AND Psicólogo & 2 & 1 & \\
\hline
\end{tabular}


go", and the combinations "Formação cientifica AND Psicólogo", "Formação em pesquisa AND Psicólogo", "Metodologia científica AND Psicologia" and "Metodologia de pesquisa AND Psicologia" produced articles to be retrieved. The selection process is in the flow chart shown in Figure 1. It can be seen in this figure that of 698 papers resulting from the initial search, 47 full papers were retrieved, of which 33 repeated, remaining 14 studies for inclusion in the analysis sample of this study (eight articles, four maters dissertations and two doctoral theses).

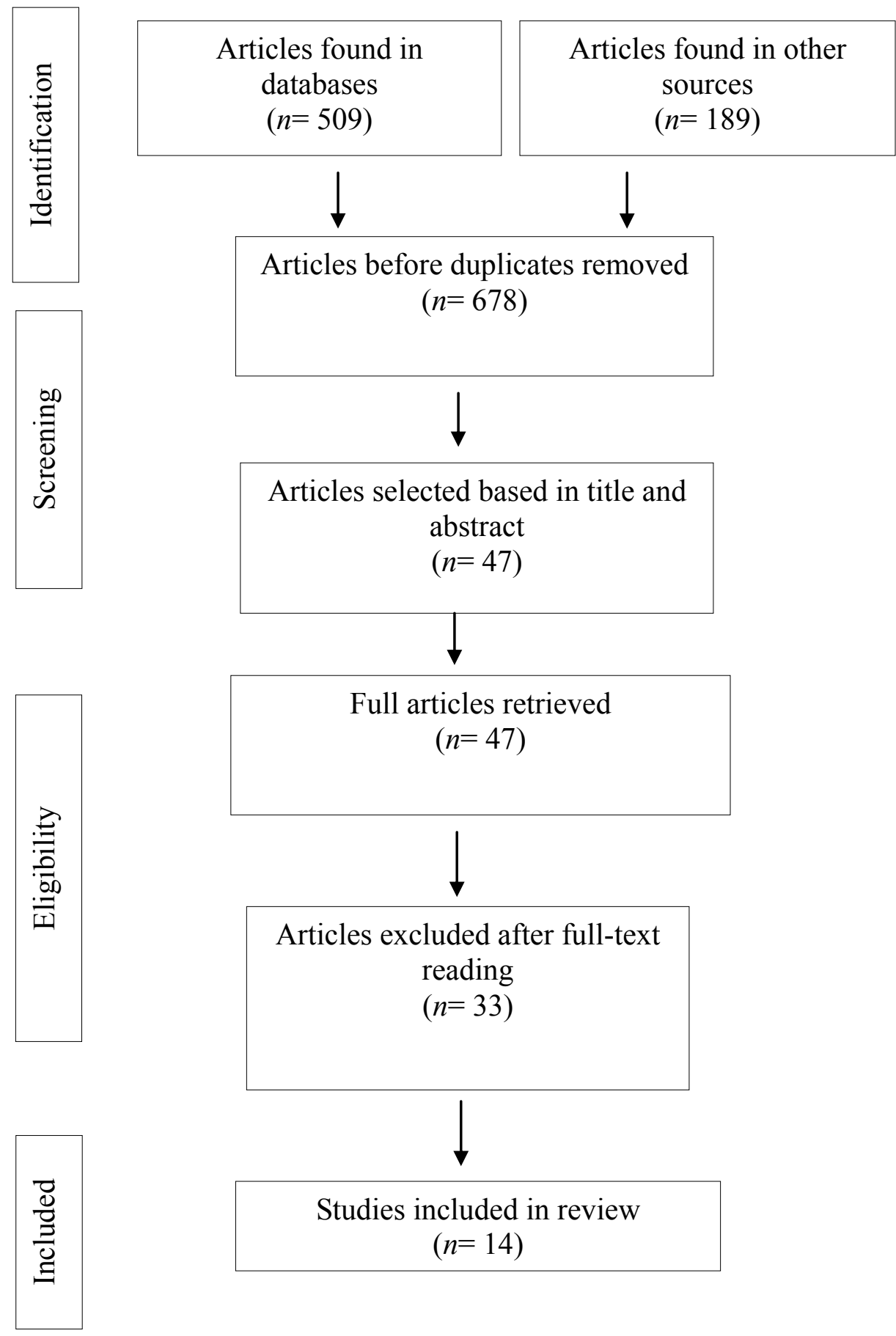

Figure 1. Flow-chart of study selection and number of studies found, selected and retrieved.

Once the documents had been read they were classified into five categories, depending on their approach to the theme of the contribution of scientific training to the professional training of psychologists. Classification was based mainly on the objective of each document, as well as 
its results and conclusions. Table 2 shows the categories and the references of the documents included in each category. What follows is a description and analysis of the documents based on the categories defined.

Table 2

Articles Selected from Databases and their Distribution According to the Categories Created for the Purpose of Classification and Analysis

\begin{tabular}{|c|c|c|c|}
\hline Number & Categories & Reference & $\begin{array}{c}\text { Type of } \\
\text { publication }\end{array}$ \\
\hline \multirow{5}{*}{1} & \multirow{5}{*}{$\begin{array}{l}\text { Conception of research, scientific training } \\
\text { and participation in research activity }\end{array}$} & Bariani (1995) & Paper \\
\hline & & Bastian et al. (2000) & Paper \\
\hline & & Guareschi, Wendt, \& Dhein (2011) & Paper \\
\hline & & Leme (2001) & Paper \\
\hline & & Seidl-de-Moura, Bosco, Diniz, \& Santos (1993) & Paper \\
\hline \multirow{3}{*}{2} & \multirow{3}{*}{$\begin{array}{c}\text { Reflection on the importance of scientific } \\
\text { training for the professional training of } \\
\text { psychologists }\end{array}$} & Ades (1981) & Paper \\
\hline & & Cruces (2008) & Paper \\
\hline & & Weber (1985) & Paper \\
\hline \multirow{4}{*}{3} & \multirow{4}{*}{$\begin{array}{l}\text { Characterization of professional } \\
\text { behaviors related to the scientific } \\
\text { training of psychologists }\end{array}$} & Goecks (2011) & Dissertation \\
\hline & & Luca (2008) & Dissertation \\
\hline & & Noceti (2011) & Dissertation \\
\hline & & Viecili (2008) & Thesis \\
\hline 4 & $\begin{array}{c}\text { Characteristics of teaching goals present } \\
\text { in course plans and teaching plans } \\
\text { for scientific training as part } \\
\text { of Psychology degree courses }\end{array}$ & Grando (2009) & Dissertation \\
\hline 5 & $\begin{array}{l}\text { Teaching programs to develop } \\
\text { professional behaviors as part of the } \\
\text { scientific training of psychologists }\end{array}$ & Luca (2013) & Thesis \\
\hline
\end{tabular}

\section{Conception of Research, Scientific Training and Participation in Research Activity}

Five of the fourteen documents analyzed were placed in the category entitled "Conception of research, scientific training and participation in research activity", as shown in Table 2. In the studies undertaken by Bariani (1995), Bastian et al. (2000) and Seild-de-Moura et al. (1993), Psychology undergraduate course students answered questionnaires so as to obtain an overall view of their knowledge and conception of scientific training, as well as their participation in research activities. Bariani's study (1995) was conducted with 43 Psychology students who were undertaking research activities, whilst the other two studies (Bastian et al., 2000; Seild-deMoura et al., 1993) were conducted with 82 and 93 students, respectively, regardless of whether or not they took part in research activities.

Leme (2001) gathered testimonies from undergraduate research students and university teachers with the aim of investigating how research training, through undergraduate research, contributes to the training of psychologists. The fifth study in this category (Guareschi et al., 2011) analyzed the answers given by Psychology students to the socio-economic questionnaire 
included in the 2006 National Students Performance Examination (Exame Nacional de Desempenho de Estudantes [ENADE] $)^{2}$. These were answers in response to questions about participation in undergraduate, assistant professor and extension course research. For the purposes of our paper, however, only the data relating to undergraduate research has been used.

Results were found in the studies falling in this category that indicate that research, in the view of the students, is considered to be important and that undertaking research activities contributes to the professional training of psychologists. In the study conducted by Seild-deMoura et al. (1993), the students replied that they consider research to be important because, among other factors, it is a "source of knowledge", enables "science to progress" and "can be a source of changes in psychology or a source of social changes" (p. 27). In addition, the students highlighted that the role of the researcher is important "because he is the agent, the subject in this process that enables the achievements attained through research" (p. 27), thus showing an idealized view remote from what happens on degree courses. The results presented by Bariani (1995) indicated that student researchers considered that taking part in research activities was of great importance for academic life and for professional training.

The testimonies gathered from the undergraduate research students in Leme's study (2001), mentioned positive aspects with regard to taking part in research activities, including the development of a more flexible relationship with knowledge, principally through the development of a more critical viewpoint and a change in ways of thinking; the fostering of autonomy and an active stance in the face of knowledge and scientific problems; as well as a relationship of sharing formed with the course supervisor. Bastian et al. (2000) began their study with the

ENADE aims to measure the level of Brazilian degree course student achievement in relation to program contents, as well as their skills and competencies. To this end, both fresher students and graduates take the examination. premise that psychologists do not value scientific research and dedicate themselves more to technical aspects of the profession. However, $99 \%$ of students replied that they considered research to be part of a psychologist's activities.

Another topic found in the studies was knowledge about research and the interest students had in doing this type of activity. Bastian et al. (2000) and Seild-de-Moura et al. (1993) indicated that students had little knowledge about research into Psychology and little interest in taking part in research. The findings of these two studies may possibly be related to another factor mentioned in all the studies in this category, which is that students receive little or no information about research activities. Bastian et al. (2000) found that $60 \%$ of the study sample $(n=82)$ were not aware of the possibility of undergraduates being able to do research activities. Moreover it is important to mention that in the study conducted by Bariani (1995) some studentresearchers replied that research is a "demanding activity", "difficult" and even "tiresome". This may also contribute to students' lack of interest in doing research.

Lack of interest and lack of knowledge about research and opportunities for doing it may have an impact on student participation in these activities, thus resulting in low participation. This fact can be seen in the study conducted by Seildde-Moura et al. (1993), in which only $10 \%$ of students in the sample $(n=93)$ were taking part or had taken part in research activities. In the study conducted by Guareschi et al. (2011), developed nationwide, $57.1 \%$ of Psychology students ( $n=23.613$ ) were not taking part or had not taken part in research activities when they were undergraduates.

Based on the findings regarding students' lack of knowledge about research and the opportunities for doing it, Bastian et al. (2000) took their study one step further and met with groups of students who had taken part in the study. This was the only study in this category publication to undertake an intervention. The objective of holding the groups was to inform the students about the findings, as well as to provide information and enlightenment about the research ac- 
tivities offered by the university in question, in an attempt to encourage student participation in research projects.

With regard to scientific training at undergraduate and postgraduate level, the teachers interviewed in the study conducted by Leme (2001) mentioned that the experience of having done undergraduate research would prepare students for their postgraduate course activities, since they would use what they learnt during undergraduate research in their postgraduate projects. Based on the replies given by students in the study conducted by Guareschi et al. (2011), when examining the sum of the indices of full, partial and limited contribution of undergraduate research to professional training, in general doing undergraduate research was considered to make the greatest contribution by students attending higher education institutions that had postgraduate programs. This fact is probably due to teachers giving greater encouragement to their students to get involved with research practices and, therefore, be more prepared for the institution's postgraduate courses.

The study conducted by Guareschi et al. (2011) also presented the replies about student participation in research activities and the percentage of the contribution of this to professional training. In this way it was found that the percentage of students who had taken part or were taking part in undergraduate research activities and considered that this experience had fully contributed to their professional training was lower than the percentage of students who were not participating or had not participated in undergraduate research activities. It is noteworthy that in the study conducted by Leme (2001), students indicated the different tutoring styles of teachers as being one of the negative points of undergraduate research, whereby some teachers treated students as mere task doers and gave them little autonomy, whilst other teachers' tutoring style was considered to be very "slack", without guidelines and leaving students not knowing how to proceed. Another negative point mentioned by students with regard to undergraduate research was its being a form of early specialization due to working with very specific research subjects, which may not be an advantage for undergraduate students.

Still in relation to participation in research activities, although more specifically in relation to the reason for seeking to do this type of activity, in Bariani's study (1995), overall students replied that when they sought to take part in research projects it was out of curiosity to know more about Psychology research and owing to their interest in learning more about research methodology. The majority of these students replied that they only had reasonable knowledge of research methodology. These results may be related to what Seild-de-Moura et al. (1993) discussed when they found a panorama of student dissatisfaction with the way research methodology was taught and scientific training was given at undergraduate level, with students referring to a low number of course disciplines covering research. Furthermore, according to the authors of this study, scientific methodology classes do not appear to meet their objectives.

In her study Bariani (1995) remarks that one of the commitments of Higher Education should be to offer scientific training as an important part of professional training. It appears, however, that this commitment is not being totally fulfilled and that greater emphasis is being placed on technical training to the detriment of scientific training. This demonstrates that these forms of training are not being seen as complementary and interdependent, but rather as distinct and also distant from each other. The author also states that universities should provide conditions for students to develop a "scientific attitude", which would be much more than just doing research, and this was also raised in the reflections made in the papers of Ades (1981) and Cruces (2008).

\section{Reflection on the Importance of Scientific Training for the Professional Training of Psychologists}

Three of the selected papers (Ades, 1981; Cruces, 2008 and Weber, 1985) were placed in the category of "Reflection on the importance of scientific training for the professional training of psychologists". Two of the articles date back to the 1980s whilst the third was written in 2008 . 
Each of them contains reflections on the scenario of the different periods in the history of Brazilian Psychology with regard to professional and scientific training. Although the periods in which they were written are distant from each other, the papers examine similar problems, indicating that the problems found in the first decade of the $21 \mathrm{st}$ century appear to be an unfolding of those appearing in the $1980 \mathrm{~s}$.

Based on a symposium held during the VIII Annual Meeting on Psychology of the Ribeirão Preto Psychology Society in 1978, entitled "Psychology training, the point of view of psychology professionals ", Ades (1981) wrote a reflection paper. As such, based on the premise that there would be no real reason for considering Psychology research and applied Psychology activities as being antagonistic or incompatible, and that integrating research and applied Psychology could only bring benefits for the training of psychologists, the author discusses "research training in psychology degree courses as a way of forming a creative attitude of investigation and theorization" (p. 113). According to the author, this is valid both for a career as a researcher and also for working professionally as a psychologist in other contexts and activities.

Data from studies conducted by other researchers in the 1970s, both in Brazil and abroad, were presented by Ades (1981), which indicate the low level of student interest in relation to research, to the detriment of the high level of interest in applied Psychology and direct psychological interventions. This finding is similar to those presented in the "Conception of research, scientific training and participation in research activity" category, comprised of the studies of Bariani (1995), Bastian et al. (2000), Guareschi et al. (2011), Leme (2001) and Seidl-de-Moura et al. (1993).

Based on the replies to a questionnaire intended for Psychology teachers prior to the VIII Annual Meeting on Psychology of the Ribeirão Preto Psychology Society in 1978, Ades (1981) informs us that 29 teachers answered the questions relating to research training and the majority stated that at the institution where they taught students did not do research activities and, furthermore, that the courses on methodology were insufficient for teaching about research. Approximately $80 \%$ of the teachers who answered these questions manifested themselves in favor of research training as part of Psychology degree courses. One of the replies stated that

unless we are only training people to apply techniques, research training is essential; perhaps not with the aim of training a person to be competent and self-sufficient in planning and conducting research, but rather to give them a "critical perspective". (Ades, 1981, p. 116)

Still with regard to scientific training and the relationship between the lack thereof and the insufficiency of scientific methodology courses, Ades (1981) states that if the intention is for students to be able to learn much more than merely reproducing fragments and techniques, they need to take part in research practice. Practical activities enable a student to present a process of behavior change facilitated by the demonstration of just how much research can contribute to professional training.

A reflection on the place of research in the training of psychologists was done by Weber (1985) based on the study he presented at the symposium "The training of Psychology researchers and the degree course - neglected responsibilities", promoted by the National Association of Psychology Research and PostGraduation. In her article the author presents reflections on the Minimum Psychology Curriculum in force at that time, as provided for by article 10 of Decree-Law No. 53464, dated January $21^{\text {st }} 1964$. The Minimum Curriculum consisted of certain obligatory disciplines that courses had to offer as well as certain optional disciplines, chosen by the higher education institutions, but none of these disciplines was specifically related scientific training. According to Weber (1985), it would not be possible to establish a Minimum Curriculum and the place of research within the Minimum Curriculum without first planning the professional training of psychologists. The author mentions that the Minimum Curriculum favored the profes- 
sionalization of psychologists, placing emphasis above all on preparation for clinical practice. However, by viewing Psychology as a science and a profession, new requirements became evident, that it was not just a question of including research disciplines on the Minimum Curriculum. It would be necessary to analyze within the educational setting how the process of students being included in research groups and taking part in research projects would take place. Effective inclusion would contribute not only to the training of researchers, but above all to the training of professionals with the capacity to be good research consumers.

Cruces (2008) sought to examine the importance of research as part of the training of psychologists by presenting an historical panorama of the preparation of this type of professional right from the beginning of the creation of Psychology courses in Brazil and the regulation of the profession in 1962. The author observed that as Psychology courses expanded, a gap began to grow between theory, research and extension, whereby research was left in the background or was not even considered during training. This fact caused problems in the professional work of psychologists, owing to what was perhaps inadequate preparation during their degree courses. This led to questioning as to the adequacy of practices used by psychologists which were not always efficacious or in keeping with reality, thus resulting in a movement of reflection regarding this situation, principally in the 1980 s, as can be seen in the papers of Ades (1981) and Weber (1985).

In her article, Cruces (2008) highlights the important role of scientific training in the production of a good professional, this role being discussed in meetings of associations and groups such as the American Psychological Association (APA), the Primera Conferencia Latinoamericana sobre Entrenamiento en Psicologia, among others. Preparation for doing research was seen as the way to train good professionals, capable of evaluating, questioning, observing, raising hypotheses and proposing efficacious interventions in keeping with needs. In Brazil, however, there were no disciplines relating to research on the Minimum Curriculum for Psychology courses. This only changed since 2004 - even though discussions as to such changes had begun in the 1980s - with effect from the National Curricular Guidelines which replaced the list of disciplines contained in the Minimum Curriculum with competencies and skills needed by psychologists, whereby scientific training was now taken into consideration and ensured.

Based on the analysis of the three papers presented in this category, it can be seen that the discussion about the place and the importance of scientific training as part of the professional training of psychologists has been present for years and, although many points still require both further discussion and, above all, changes, progress has been made in terms of public policies on the teaching of Psychology. Nevertheless, such progress needs to be guaranteed through the practices in place within the institutions, ranging from Psychology course plans through to the way in which scientific training takes place and how the disciplines of scientific methodology are taught. Analysis should also be made of the extent to which the research training that has been provided in higher education institutions has contributed to improving the quality of professional training, bearing in mind what type of professionals universities wish to produce.

\section{Characterization of Professional Behaviors Related to the Scientific Training of Psychologists}

Among the studies selected, four (Goecks, 2011; Luca, 2008; Noceti, 2011 and Viecili, 2008) were categorized as "Characterization of professional behaviors related to the scientific training of psychologists". The objective of all the studies in this category was to identify what classes of behavior are general classes with regard to academic, professional and scientific behaviors which in this article are related to the scientific training of psychologists. The general classes of behaviors studied include "evaluating the reliability of information" (Luca, 2008), "delimiting research problems based on questions" (Noceti, 2011), "reading academic texts" (Goecks, 2011) and classes of 
professional behavior that comprise the training of psychologist to intervene indirectly through research (Viecili, 2008).

The characterization of the behavior classes that comprise someone's work or function in society consists of one of several stages - and perhaps the most important - of Programmed Teaching, which is a teaching technology based on the Experimental Analysis of Behavior (Kienen, Kubo, \& Botomé, 2013). With regard to the stages, as a general rule the first stage is the characterization of the social needs of the learner. Based on this the behaviors are identified which need to be learnt so that the learner can cope better with these needs. Learning these behaviors is what will enable them to transform the social reality they face once the learning period is over. This first stage of identifying and characterizing the behaviors that will comprise the learner's performance in society will enable the planning of several other stages in which these behaviors are effectively taught. Once this has been done teaching conditions can be programmed so that the behaviors are developed and at this stage activities to achieve this are proposed. Evaluation of the efficiency and efficacy of teaching programs is the final part of the Programmed Teaching process and this will enable the enhancement of the teaching program developed.

The studies in this category emphasize that characterizing behavior classes is important since it enables one to know what should be taught in order to train future professionals and researchers. In this way, based on the identification of the behaviors that comprise the general classes studied, it is possible for teachers to formulate clear teaching objectives and plan activities for developing these behaviors.

The study conducted by Viecili (2008) sought to identify behavior classes related to the professional training of psychologists to intervene through research. Viecili's study was based on the National Curricular Guidelines for Psychology Degree Courses and on degree course projects of different teaching institutions in Brazil. According to the author, the behavior classes identified and the gaps in some behavior classes indicate that many behavior classes relating to the scientific training of psychology professionals have yet to be discovered, so that they can collaborate with the organization of Psychology courses in order to ensure the development of scientific behaviors that are fundamental for psychologists.

With the aim of completing and enhancing one of the behavior classes characterized by Viecili (2008), namely the class relating to the delimitations of the research problem, Noceti (2011) sought to identify the behaviors that make up the general class of "delimiting research problems based on questions" derived from a research manual. The author highlights that "delimiting a problem" is part of the process of producing scientific knowledge and is one of the initial stages of this process.

In the same way, "evaluating the reliablity of information" (Luca, 2008) and "reading academic texts" (Goecks, 2011) are academic behaviors of great importance for the professional and scientific training of students, since by developing them it is possible to develop other professional behaviors that will be necessary in the diverse areas of their work. Furthermore, it is important to highlight that "reading academic texts" and "evaluating the reliability of information" are behaviors required throughout degree courses, as well as for postgraduate courses and in professional life. However, although they do not appear to be objects of study as general classes of behaviors, these repertoires are frequently found to be insufficient or unsatisfactory by students.

Viecili (2008) states that when a student learns about research as a set of techniques and procedures, it is likely that they will not learn to identify when intervention is needed but rather simply reproduce the techniques they learnt, as indicated by Ades (1981). Viecili (2008) also highlights that quality scientific training needs to be guaranteed as part of the training of psychologists in order to enable the field of their professional work to be broadened and thus meet the needs present in society. Thus, based on the characterization of the professional behaviors that comprise the scientific training 
of psychologists it is possible to formulate clear teaching objectives that enable the preparation of teaching programs to develop such behaviors. Studies aimed at characterizing other behavior classes related to the scientific training of psychologists or related to the enhancement and expansion of classes already characterized can contribute to more efficacious teaching of such behaviors, resulting in professional training that ensures that students have the capacity to intervene through research.

\section{Characteristics of Teaching Goals Present in Course Plans and Teaching Plans for Scientific Training as Part of Psychology Degree Courses}

The purpose of the study performed by Grando (2009) was to characterize which scientific behaviors are proposed for course and discipline teaching plans relating to the scientific training of Psychology undergraduate students. In her study the author questions whether Psychology degree courses are training future professionals to produce knowledge, so that this scientific activity could lead to graduated psychologists seeking technologies and procedures that are more efficacious and adequate for the diverse demands they face as professionals.

After having identified the characteristics of the teaching objectives contained in the plans of the courses and disciplines related to the scientific training of psychologists, the author divides them into four categories: student academic activities or actions; vague, generic or ambiguous expressions; statements of intent and teacher activities or actions. In her study, Grando (2009) concluded that few teachers had formulated clear teaching objectives explicitly stating which behaviors students should learn as part of the activities of the discipline in question. The teaching objectives were frequently found to have been presented in broad terms, containing the description of the disciplines or the activity that the teacher will undertake and not the description of the behavior the student is expected to be able to demonstrate. In this way, the contribution made by Grando's (2009) paper is that studying the characteristics of the teaching objectives contained in the plans of the courses and disciplines related to the scientific training as part of Psychology degree courses may make it possible for teachers to formulate plans with clearer and more precise objectives with regard to the target behaviors to be developed. In this way, by having better quality professional and scientific training, future professionals would be more capable of becoming autonomous and producing scientific knowledge, both as researchers and also in teaching and intervention activities in different working areas.

\section{Teaching Programs to Develop Professional Behaviors as Part of the Scientific Training of Psychologists}

This category was created based on the study developed by Luca (2013) in his Ph.D. thesis. Based on the characterization of components of basic behaviors comprising the general class referred to as "evaluating the reliability of information" which was the subject of his Master's Degree dissertation (Luca, 2008), in his $\mathrm{Ph}$.D. thesis he aimed to evaluate the degree of efficiency and efficacy of a teaching program in developing classes of behavior comprising the general class he characterized.

The Teaching Program for the general class of "evaluating the reliability of information", comprised of 866 behavior classes, 136 of which were selected to be taught, was applied to two groups: (a) the History Group, comprised of three learners taking a History degree and 13 sessions to develop the behaviors characterized; and (b) the Psychology Group, comprised on four learners taking a Psychology degree and 15 sessions. The Program's efficiency was assessed by evaluating the individual performance of the learners in relation to the development of each of the behaviors proposed in the teaching program.

The evaluation of the efficacy of the teaching program was done by means of follow up five months after the Program ended. This involved the application of another activity as well as an interview on the implications and contributions perceived by the learners from what they had learnt through the program in different contexts. The teaching program was found to have a high 
degree of efficiency in terms of developing the behaviors comprising the general class of "evaluating the reliability of information" and a high degree of efficacy was found during follow up. The author considers that the efficiency and efficacy of the Program were probably determined by the way it was prepared, as it was guided by the principles of Experimental Analysis of Behavior and this was seen to have contributed to ensuring that the behaviors were developed.

The learners reported a series of positive implications produced by what they learnt through the Program (Luca, 2013), such as: improved quality of their own oral discourse, improved quality of written work, identification and examination of prejudiced information, better substantiated conclusions, putting forward complete and reliable arguments in speeches, among other implications. These reports appear to demonstrate that the program was efficient in the development of behavior classes that are important for professional activities, in particular those of psychologists. Some of the implications reported were not behaviors intended to be achieved by the program, thus showing that the learning process appears to have provided a basis for other behaviors to be developed outside of the learning context. This indicates an even greater contribution of this type of program to the professional and scientific training of students. It is noteworthy that several of these behavior classes could be characterized as part of the scientific training of psychologists in preparation for them being able to work in any professional field or level.

\section{Final Considerations}

Based on the analysis of the documents selected, the contributions of these studies to the examination of the importance of scientific training as part of the professional training of future psychologists can be identified. The authors were unanimous as to the fundamental role of research training as a necessary and inextricable part of good professional training. In the 1980s and 1990s, through the discussions on the ab- sence of a place for research on the Minimum Curriculum, this fact resulted in the National Curricular Guidelines for Psychology degree courses (Cruces, 2008). However, despite the teaching of research being guaranteed during the degree courses of future psychologists, they do not make explicit how such training will take place and it often becomes the mere reproduction of techniques and procedures taken from the well-known research manuals (Viecili, 2008).

It appears that progress still needs to be made with regard to the way in which scientific training takes place so that research is not seen in an idealized and uninteresting manner by students. As many students are not interested in continuing in the academic world as teachers and researchers, they take on a stance of being people who do not do research, as if research were exclusively what is done formally within undergraduate research projects, laboratories and compulsory activities within scientific methodology disciplines and not as something that is also a foundation for professional practice. It is probable that this is due in great part to the lack of publicizing of opportunities for research experiences. This in itself is a reason for finding alternatives that encourage students to seek such activities (Bariani, 1995; Bastian et al., 2000).

Much of the lack of interest is also related to the lack of knowledge about the extent to which this experience will in fact add to the development of behaviors that will be useful for future professional activities. This appears to indicate lack of knowledge about behaviors that comprise scientific activities on the part of students, psychologists and even some teachers. It is not difficult to understand why uninteresting research training, disconnected from the benefits it can have for professionals and which does not make sense to the reality of undergraduate students has shortcomings. As such, in addition to the important questioning of the social, political and historical aspects underlying the current condition of higher education, reflection should also take place as to what kind of practical changes could be suggested as possible ways to improve the quality of the professional training of psychologists. 
Perhaps it may also be pertinent to reflect on which behaviors relating to scientific activities could be developed and what conditions would be needed for this to happen (Grando, 2009; Noceti, 2011; Viecili, 2008). Therefore, considering that scientific training is important as part of the training of future Psychology professionals, in what ways is it possible and necessary to teach research at the present time? It is probable that the answer to this question will not indicate just one single way forward or some sort of teaching "formula".

The studies based on Programmed Teaching in this article appear to bring relevant contributions to this issue by presenting it as an efficacious technology for understanding and developing scientific/professional behaviors (Goecks, 2011; Grando, 2009; Luca, 2008, 2013; Noceti, 2011 and Viecili, 2008). Further studies complementing the characterization of the behaviors presented and evaluating teaching programs for the development of other general classes of behavior related to research can form a promising way forward in the quest for efficacious and quality training. It should be highlighted that the inclusion of the studies done by the Santa Catarina Federal University Psychology Postgraduate Program group reflects that as yet there is little variety of research in this area and that these are concentrated on research produced by that specific group.

\section{References}

Ades, C. (1981). Treino em pesquisa, treino em compreensão. Psicologia: Ciência e Profissão, 1(1), 107-140.

Bariani, I. C. D. (1995). Um estudo exploratório sobre os motivos e os significados associados a prática da pesquisa em estudantes universitários. Estudos de Psicologia (Campinas), 12(1), 57-63.

Bastian, F. S., Amoretti, J., Rocha, K. B., Lisboa, C. S. de M., Kude, V. M. M., \& Wagner, A. (2000). Despertando o interesse pela pesquisa científica em psicologia. Psico, 31(1), 123-131.

Cruces, A. V. V. (2008). A pesquisa na formação de psicólogos brasileiros e suas políticas públicas. Boletim: Academia Paulista de Psicologia, 28(2), 240-255.
Decree-Law No. 53464, January $21^{\text {st }}$ 1964. (1964, January 24). Diário Oficial da União.

Goecks, C. A. (2011). Comportamentos constituintes da classe geral de comportamentos "ler textos acadêmicos" (Master's thesis, Universidade Federal de Santa Catarina, Florianópolis, SC, Brazil). Retrieved from http://repositorio.ufsc. br/xmlui/handle/123456789/95870

Grando, A. P. (2009). Características dos objetivos de ensino presentes nos planos de curso e de ensino de disciplinas relacionadas à capacitação cientifica de alunos de cursos de graduação em psicologia (Master's thesis, Universidade Federal de Santa Catarina, Florianópolis, SC, Brazil). Retrieved from http://repositorio.ufsc. br/xmlui/handle/123456789/92843

Guareschi, N. M. de F., Wendt, G. W., \& Dhein, G. (2011). As atividades de pesquisa, extensão e monitoria na formação em psicologia. Avaliação Psicológica, 19(3), 387-403.

Kienen, N., Kubo, O. M., \& Botomé, S. P. (2013). Ensino programado e programação de condições para o desenvolvimento de comportamentos: Alguns aspectos no desenvolvimento de um campo de atuação do psicólogo. Acta Comportamentalia, 21(4), 481-494.

Leme, M. I. da S. (2001). Iniciação à pesquisa científica. Psicólogo inFormação, 5(5), 25-34.

Luca, G. G. (2008). Características de componentes de comportamentos básicos constituintes da classe geral de comportamentos denominada "avaliar a confiabilidade de informações" (Master's thesis, Universidade Federal de Santa Catarina, Florianópolis, SC, Brazil). Retrieved from https://repositorio.ufsc.br/bitstream/handle/123456789/91008/262431.pdf?sequence $=1$

Luca, G. G. (2013). Avaliação da eficácia de um programa de contingências para desenvolver comportamentos constituintes da classe geral "avaliar a confiabilidade de informações" (Doctoral dissertation, Universidade Federal de Santa Catarina, Florianópolis, SC, Brazil).

Ministério da Educação, Conselho Nacional de Educação/Câmara da Educação Superior (2011). Resolução ${ }^{\circ} 5$, aprovada em 15/03/2011, fixa as Diretrizes Curriculares Nacionais para os cursos de graduação em Psicologia, estabelecendo normas para o projeto pedagógico complementar para a Formação de Professores de Psicologia. Brasília, DF: Autor." 
Noceti, R. V. (2011). Classes de comportamentos constituintes da classe geral "delimitar problema de pesquisa a partir de perguntas" (Master's thesis, Universidade Federal de Santa Catarina, Florianópolis, SC, Brazil). Retrieved from http://repositorio.ufsc.br/xmlui/ handle/123456789/95473

Seidl-de-Moura, M. L., Bosco, E., Diniz, L. F., \& Santos, T. G. (1993). A pesquisa em psicologia e o aluno de graduação. Psicologia: Reflexão $e$ Crítica, 6(1-2), 17-38.

Silva, K. L. (2007). Comportamentos que constituem a classe geral delimitar problema de pesquisa no trabalho cientifico de alunos de pós-graduação em psicologia (Master's thesis, Universidade Federal de Santa Catarina, Florianópolis, SC, Brazil). Retrieved from http://repositorio. ufsc.br/xmlui/handle/123456789/89946

Viecili, J. (2008). Classes de comportamentos profissionais que compõem a formação do psicólogo para intervir por meio de pesquisa sobre fenômenos psicológicos, derivadas a partir das diretrizes curriculares nacionais para cursos de graduação em psicologia $e$ da formação desse profissional (Doctoral dissertation, Universidade Federal de Santa Catarina, Florianópolis, SC, Brazil). Retrieved from http://www.cfh.ufsc.br/ ppgp/Juliane $\% 20$ Viecili.pdf

Weber, S. (1985). Currículo mínimo e o espaço da pesquisa na formação do psicólogo. Psicologia Ciência e Profissão, 5(2), 11-13. doi:10.1590/ S1414-98931985000200004
Recebido: 17/11/2014

$1^{a}$ revisão: $28 / 04 / 2015$

Aceite final: 07/05/2015 